\title{
PERTUMBUHAN DAN KELANGSUNGAN HIDUP IKAN HIAS PLATYDORAS (Platydoras costatus) DALAM TEKNOLOGI BIOFLOK
}

\section{GROWTH AND GOING FISH LIFE PLATYDORAS (Platydoras costatus) FISH IN BIOFLOK TECHNOLOGY}

\author{
A Teduh' ${ }^{1 a}$, Muarif ${ }^{2}$, dan Rosmawati ${ }^{1}$ \\ ${ }^{1}$ Jurusan Perikanan, Fakultas Pertanian, Universitas Djuanda Bogor Jl. Tol Ciawi No. 1, Kotak Pos 35 \\ Ciawi, Bogor 16720. \\ a Korespondensi: Ahmad Teduh, E-mail: teduhahmad@yahoo.com \\ (Diterima: 12-07-2017; Ditelaah: 12-07-2017; Disetujui: 29-09-2017)
}

\begin{abstract}
The purpose of this research is to know the growth and survival of Platydoras ornamental fish (Platidoras costatus) which is maintained by using biofloc technology. This study used Completely Randomized Design with 2 treatments and 5 replications. The treatments in this study were: Treatment A (Without Biofluok), B (With Bioflok). The test fish used are Platydoras ornamental fish that has a length of 1.9-2.1 cm. Fish kept for 40 days and fed 2 times a day. The parameters observed included daily growth rate, survival, water quality measurement and bacterial density. The results showed that the addition of bioflock gave significant different effect $(\mathrm{P}<0,05)$ to daily growth rate, and survival rate $(\mathrm{SR})$. The density of the bacteria at the start of the study (9.6x104 CFU / ml), at the end of the study had an average value of treatment without biofloc ranging from $7.84 \times 105 \mathrm{CFU} / \mathrm{ml}$ while the mean value of biofloc treatment ranged from $4.3 \times 106$ CFU / ml, at the beginning of the study there were 4 types of bacteria: Streptobacillus sp, Enterobacter sp, Kurthia sp, Aeromonas sp. at the end of the study there were 2 types of bacteria on treatment without biofloc (Streptobacillus sp and Aeromonas sp) and 2 types of bacteria on biofloc treatment (Streptobacillus sp and Kurthia sp.).
\end{abstract}

Keywords: biofloc, growth, platydoras, type of bacteria.

\begin{abstract}
ABSTRAK
Tujuan penelitian ini untuk mengetahui pertumbuhan dan kelangsungan hidup ikan hias Platydoras (Platidoras costatus) yang dipelihara dengan menggunakan teknologi bioflok. Penelitian ini menggunakan Rancangan Acak Lengkap dengan 2 perlakuan dan 5 ulangan. Perlakuan dalam penelitian ini adalah: Perlakuan A (Tanpa Bioflok), B (Dengan Bioflok). Ikan uji yang digunakan adalah ikan hias Platydoras yang memiliki panjang 1,9-2,1 cm. Ikan dipelihara selama 40 hari dan diberi pakan 2 kali sehari. Parameter yang diamati meliputi laju pertumbuhan harian, kelangsungan hidup, pengukuran kualitas air dan kepadatan bakteri. Hasil penelitian menunjukan bahwa penambahan bioflok memberikan pengaruh yang berbeda nyata $(\mathrm{P}<0,05)$ terhadap laju pertumbuhan harian, dan tingkat kelangsungan hidup (SR). Kepadatan bakteri di awal penelitian $\left(9.6 \times 10^{4} \mathrm{CFU} / \mathrm{ml}\right)$, pada akhir penelitian memiliki nilai rata-rata pada perlakuan tanpa bioflok berkisar $7.84 \times 10^{5} \mathrm{CFU} / \mathrm{ml}$ sedangkan nilai rata-rata pada perlakuan bioflok berkisar 4,3 x106 $\mathrm{CFU} / \mathrm{ml}$, Hasil indentifikasi pada awal penelitian terdapat 4 jenis bakteri yaitu Streptobacillus sp, Enterobacter sp, Kurthia sp, Aeromonas sp. pada akhir penelitian terdapat 2 jenis bakteri pada perlakuan tanpa bioflok (Streptobacillus sp dan Aeromonas sp) dan 2 jenis bakteri pada perlakuan bioflok (Streptobacillus sp dan Kurthia sp.).

Kata kunci: bioflok, pertumbuhan, platydoras, jenis bakteri.
\end{abstract}


Teduh A, Muarif, dan Rosmawati. 2017. Pertumbuhan dan kelangsungan hidup ikan hias platydoras (Platydoras costatus) dalam teknologi bioflok. Jurnal Pertanian 8(2): 66-73.

\section{PENDAHULUAN}

Ikan Platydoras merupakan salah satu ikan hias yang memiliki kelebihan, yaitu memiliki perilaku yang menyenangkan serta sifat rasa ingin tahunya. Ikan ini biasanya ditemukan di sungai Amazon, Tocantins, Parnaíba, Orinoco, serta sungai Essequibo di Brazil, Guyana Prancis, dan juga Suriname. Ikan ini bersifat nokturnal, sehingga lebih sering terlihat dan aktif pada malam hari. Kondisi air yang diperlukan adalah pH 5,8-7,0, temperatur 26$28{ }^{\circ} \mathrm{C}$, substrat yang digunakan lebih baik berupa pasir atau kerikil yang halus karena sifat ikan ini yang suka menggali (Axelrod 1988).

Masalah yang timbul pada budidaya intensif adalah degradasi kualitas air terutama diakibatkan penggunaan pakan yang cukup tinggi. Salah satu solusi mengatasi masalah degradasi kualitas perairan agar tetap terjaga baik untuk kehidupan maupun pertumbuhan ikan adalah dengan penerapan teknologi bioflok. Teknologi bioflok ini didasarkan pada kemampuan bakteri heterotrof dalam mengkonversi nitrogen baik organik maupun anorganik yang terdapat dalam air menjadi biomassa bakteri (De Schryver dan Verstraete 2009). Bioflok merupakan suatu agregat yang tersusun atas bakteri pembentuk flok, bakteri filament, mikroalga (fitoplankton), zooplankton, jamur dan virus (Browdy et al. 2012) dan dapat mencapai ukuran $1000 \mu$ m (De Schryver et al. 2008).

Penelitian tentang teknologi bioflok selama ini banyak diterapkan pada budidaya ikan konsumsi seperti budidaya udang vanamei, ikan nila dan ikan lele (Avnimelech 2012), sedangkan untuk budidaya ikan hias air tawar masih sedikit. Oleh karena itu dalam penelitian ini akan mencoba menerapkan teknologi bioflok pada budidaya ikan hias Platydoras sebagai komoditas ikan hias air tawar. Penelitian ini dilakukan untuk mengetahui pertumbuhan dan kelangsungan hidup ikan hias Platydoras yang dipelihara dengan menggunakan teknologi bioflok.

\section{MATERI DAN METODE}

\section{Waktu dan Tempat}

Percobaan ini dilaksanakan pada Bulan September 2016 sampai Desember 2016 bertempat di Edoe Fish Farm, Ciampea, Kabupaten Bogor.

\section{Bahan dan Alat Penelitian}

Peralatan yang akan digunakan dalam penelitian ini adalah akuarium berukuran $60 \mathrm{~cm} \times 40 \mathrm{~cm} \times 30 \mathrm{~cm}$ sebanyak 10 buah, blower, batu aerator dan selang aerasi. Selang sifon diperlukan untuk penyifonanan., timbangan digital, baskom, termometer, DO meter, $\mathrm{Ph}$ meter. Bahan yang digunakan adalah ikan hias Platydoras berukuran SM (1,5-1,8 cm) dan Pakan.

\section{Metode Penelitian}

\section{Rancangan Percobaan}

Rancangan yang digunakan dalam percobaan adalah Rancangan Acak Lengkap (RAL) yang terdiri dari dua perlakuan dan lima kali ulangan. Perlakuan A yaitu budidaya ikan platydoras tanpa teknologi bioflok dan perlakuan B yaitu budidaya ikan platydoras dengan teknologi bioflok.

\section{Prosedur Penelitian Persiapan Wadah}

Akuarium berukuran $60 \mathrm{~cm} \times 40 \mathrm{~cm} \times 30 \mathrm{~cm}$ sebanyak 10 buah untuk 2 perlakuan dengan masing-masing perlakuan dilakukan lima kali ulangan. Saluran outlet pada wadah dipasang selang aerasi. Wadah dicuci dengan menggunakan deterjen, selanjutnya wadah diisi dengan air dengan perlakuan bioflok dan tanpa bioflok hingga ketinggian $20 \mathrm{~cm}$. Ikan platydoras selanjutnya siap ditebar ke dalam wadah percobaan. 


\section{Persiapan Hewan Uji}

Platydoras diperoleh dari pembudidaya ikan hias yang berasal dari Laladon Bogor dan dikirim ke Edoe fish farm melalui jalur darat dengan sistem transpotasi tertutup, lalu dikarantina selama 1 minggu untuk mengurangi stres. Proses selanjutnya Platydoras ditebar di wadah akuarium percobaan dengan perlakuan bioflok dan tanpa perlakuan bioflok.

\section{Pemeliharaan}

Masa pemeliharaan 40 hari, dengan padat tebar 1000 ekor $/ \mathrm{m}^{2}$ (240e/akuarium). Pakan yang diberikan yaitu pellet Fengli 1 (F1) dengan dosis pemberian sebanyak $5 \%$ dari bobot biomassa dan frekwensi dua kali sehari yaitu pada pukul 07.00 WIB dan 17.00 WIB. Media pemeliharaan ikan yang dipelihara tanpa teknologi bioflok (perlakuan A), dilakukan penggantian air sebesar 30\%/hari untuk menjaga kualitas air tetap baik, sedangkan pemeliharaan dengan teknologi bioflok dilakukan tanpa penggantian air (minimal penggantian air), namun setiap minggu volume air dikontrol dan apabila air berkurang karena penguapan, maka dilakukan penambahan air secukupnya.

Perlakuan dengan teknologi bioflok (perlakuan B) menggunakan sumber karbon molase dengan (kadar karbon sebesar $45,27 \%$ ) dan rasio $\mathrm{C} / \mathrm{N} 10$, rasio ini berdasarkan hasil penelitian Diatin dan Harris (2014) pada budidaya ikan Corydoras $s p$ secara intensif menggunakan teknologi bioflok pada rasio $\mathrm{C} / \mathrm{N} 10$ menghasilkan kinerja produksi yang lebih baik dibandingin rasio C/N 15 (Diatin dan Harris 2014). Untuk pembentukan bioflok, terlebih dahulu diberikan inokulan bioflok yang diperoleh dari Laboratorium Sistek Budidaya Perairan Fakultas Perikanan Ilmu Kelautan Institute Pertanian Bogor masing-masing sebanyak $250 \mathrm{ml} /$ akuarium. Setelah sekitar seminggu selanjutnya ikan ditebar. Molase diberikan setiap hari sekitar 2 jam setelah pemberian pakan fengli 1, kebutuhan molase setiap hari dihitung berdasarkan rumus De Schryver et al. (2008). Pengambilan sampel untuk mengukur panjang dan bobot ikan serta pengukuran kualitas air seperti suhu, DO, dan
pH, kekeruhan, alkalinitas, amonia, nitrit, nitrat, dan volume flok dilakukan setiap sepuluh hari sekali.

\section{Parameter yang Diamati Kelangsungan Hidup}

Kelangsungan hidup adalah perbandingan jumlah ikan yang hidup sampai akhir pemeliharaan dengan jumlah ikan pada awal pemeliharaan. Derajat kelangsungan hidup dihitung menggunakan rumus dari Goddard (1996) yaitu:

$$
D K=\left(\frac{N_{t}}{N_{0}}\right) \times 100 \%
$$

Keterangan: $\mathrm{DK}=$ derajat kalangsungan hidup (\%); $\mathrm{N}_{0}=$ jumlah ikan pada awal pemeliharaan (ekor); $\mathrm{N}_{\mathrm{t}}=$ jumlah ikan pada akhir pemeliharaan (ekor).

\section{Laju Pertumbuhan Bobot Harian}

Bobot ikan diukur dengan pengambilan contoh sebanyak 20 ekor per akuarium. Laju pertumbuhan bobot harian dihitung dengan menggunakan rumus dari Goddard (1996)

$$
\alpha=\frac{\ln (\varpi t)-\ln (\varpi o)}{t} \times 100 \%
$$

Keterangan: $\alpha=$ laju pertumbuhan bobot harian individu (\%); $\varpi t=$ bobot rata-rata pada akhir pemeliharaan (g/ekor); $\varpi O=$ bobot ratarata pada awal pemeliharaan (g/ekor); $\mathrm{t}=$ periode pemeliharaan (hari).

\section{Kepadatan Bakteri}

Jumlah bakteri pada wadah pemeliharaan dan jenis bakteri yang dominan diukur pada awal pemeliharaan dan akhir pemeliharaan. Pengukuran di laboratorium Departemen Budidaya Perairan Fakultar Perikanan Ilmu Kelautan Institute Pertanian Bogor.

\section{Pengukuran Kualitas Air}

Pengukuran kualitas air dalam penelitian dilakukan secara rutin setiap 10 hari sekali. Adapun beberapa parameter kualitas air yang diukur dalam penelitian ini dapat dilihat pada Tabel 1.

\section{Analisis Data}

Data yang telah diperoleh kemudian ditabulasi dan dianalisis. Data parameter 
derajat kelangsungan hidup, laju perlakuan berpengaruh nyata terhadap pertumbuhan bobot harian dianalisis derajat kelangsungan hidup, laju menggunakan analisis ragam (ANOVA) pada pertumbuhan bobot harian. Apabila selang kepercayaan 95\%. Analisis ini digunakan untuk menentukan apakah berpengaruh nyata.

Tabel 1 Parameter kualitas air

\begin{tabular}{llll}
\hline Parameter & Satuan & Metode/ Alat & $\begin{array}{l}\text { Waktu } \\
\text { Pengukuran }\end{array}$ \\
\hline Suhu & & Termometer & 10 hari/ 1 kali \\
pH & ${ }^{\circ} \mathrm{c}$ & pH-meter & 10 hari/ 1 kali \\
Kekeruhan & - & & 10 hari/ 1 kali \\
DO & NTU & DO-meter & 10 hari/ 1 kali \\
TAN & $\mathrm{mg} / \mathrm{m} / \mathrm{m}$ & & 10 hari/ 1 kali \\
\hline
\end{tabular}

\section{HASIL DAN PEMBAHASAN}

\section{Hasil}

\section{Laju pertumbuhan Harian Ikan Hias Platydoras}

Hasil pengukuran laju pertumbuhan harian ikan hias Platydoras pada akhir penelitian setelah 40 hari pemeliharaan tanpa bioflok dan bioflok disajikan pada Tabel 2 .

Tabel 2 Laju pertumbuhan harian (\%)/hari ikan hias platydoras selama penelitian

\begin{tabular}{lrr}
\hline \multirow{2}{*}{ Ulangan } & \multicolumn{2}{c}{ Perlakuan } \\
\cline { 2 - 3 } & Tanpa Bioflok & \multicolumn{1}{c}{ Bioflok } \\
\hline 1 & 2.40 & 3.10 \\
2 & 2.41 & 2.92 \\
3 & 2.91 & 2,97 \\
4 & 2,94 & 3.28 \\
5 & 3.04 & 3.32 \\
Rata-Rata & $2.74 \pm 0.15$ & $3.17 \pm 0.17$ \\
\hline
\end{tabular}

Berdasarkan uji analisis ragam pada selang kepercayaan 95\% menunjukkan bahwa perlakuan tanpa bioflok dan bioflok memberikan pengaruh berbeda nyata
$(\mathrm{P}<0,05)$ terhadap laju pertumbuhan harian ikan hias Platydoras.

\section{Kelangsungan Hidup}

Hasil pengukuran tingkat kelangsungan hidup ikan hias Platydoras yang dipelihara selama 40 hari disajikan pada Tabel 3. Berdasarkan uji analisis ragam pada selang kepercayaan 95\%, menunjukkan hasil yang berbeda nyata $(\mathrm{P}<0,05)$.

Tabel 3 Kelangsungan hidup (\%) ikan hias platydoras selama penelitian

\begin{tabular}{lrr}
\hline \multirow{2}{*}{ Ulangan } & \multicolumn{2}{c}{ Perlakuan } \\
\cline { 2 - 3 } & Tanpa Bioflok & \multicolumn{1}{c}{ Bioflok } \\
\hline 1 & 84.17 & 72.08 \\
2 & 87.50 & 78.75 \\
3 & 84.58 & 80.42 \\
4 & 90.00 & 75.42 \\
5 & 84.17 & 71.67 \\
Rata-Rata & $86.08 \pm 2.60$ & $75.67 \pm 3.90$ \\
\hline
\end{tabular}

\section{Kepadatan Bakteri}

Hasil pengukuran di laboratorium Budidaya Peraian Fakultas Perikanan Ilmu Kelautan Institute Pertanian Bogor pada awal pemeliharaan dan akhir pemeliharaan. 
Tabel 4 Kepadatan dan jenis bakteri

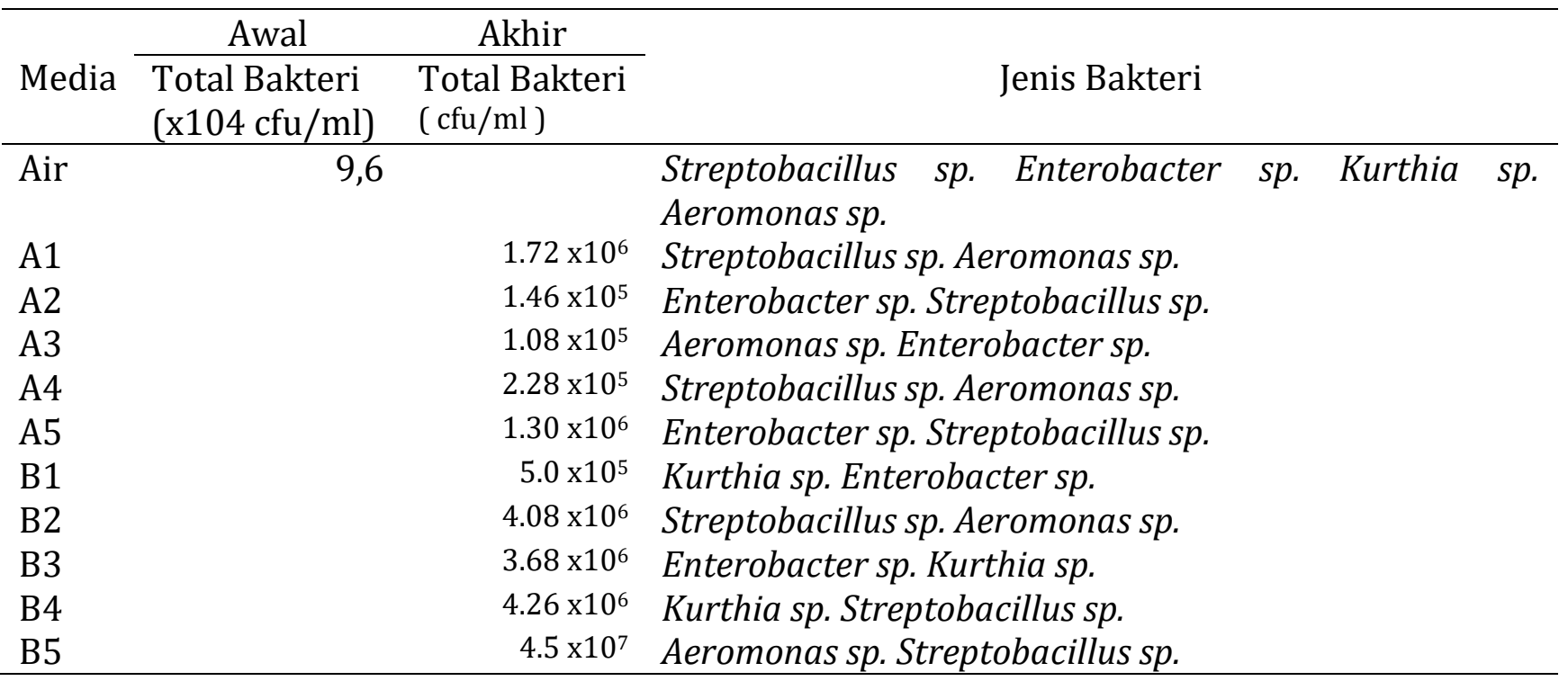

\section{Kualitas Air}

Kualitas air dan kepadatan bakteri merupakan faktor lain yang juga mempunyai peranan penting dalam menunjang kelangsungan hidup dan pertumbuhan ikan hias Platydoras. Hasil pengukuran dari beberapa parameter kualitas air selama penelitian disajikan pada Tabel 5 .

Tabel 5 Nilai kualitas air selama penelitian

\begin{tabular}{lrr}
\hline & \multicolumn{2}{c}{ Perlakuan } \\
\cline { 2 - 3 } Parameter & \multicolumn{1}{c}{ Tanpa } \\
& \multicolumn{1}{c}{ Bioflok } & \multicolumn{1}{c}{ Bioflok } \\
\hline Suhu $\left({ }^{0} \mathrm{C}\right)$ & $26.9-27.9$ & $26.9-27.8$ \\
$\mathrm{pH}(\mathrm{mg} / \mathrm{l})$ & $6.1-6.5$ & $6.1-6.6$ \\
DO $(\mathrm{mg} / \mathrm{l})$ & $5.9-7.7$ & $5.5-7.2$ \\
Kekeruhan & $19.0-32.0$ & $52.0-86.0$ \\
(NTU) & & $0.003-1.092$ \\
\hline
\end{tabular}

\section{Pembahasan}

\section{Laju Pertumbuhan Harian}

Hasil penelitian menunjukkan bahwa penggunaan bioflok pada ikan hias Platydoras berbeda nyata $(\mathrm{P}<0.05)$ terhadap laju pertumbuhan harian ikan hias Platydoras yang dipelihara selama 40 hari. Nilai laju pertumbuhan harian pada penelitian tanpa menggunakan teknologi bioflok sebesar $2,74 \pm 0,15 \%$ dan menggunakan teknologi bioflok sebesar 3,11 $\pm 0,17 \%$. Pertumbuhan di pengaruhi oleh dua faktor yaitu faktor intrinsik (dalam) dan ekstrinsik (luar). Faktor intrinsik meliputi sifat keturunan, umur, ukuran, ketahanan terhadap penyakit dan kemampuan memanfaatkan makanan, sedangkan faktor ekstrinsik meliputi sifat fisik dan kimiawi perairan serta komponen hayati seperti ketersediaan makanan dan kompetisi (Raharjo et al. 2011). Berdasarkan hal tersebut makanan merupakan faktor utama penentu pertumbuhan karena tanpa makanan tidak ada asupan energi untuk tumbuh.

Ikan Platydoras yang dipelihara pada teknologi bioflok mendapatkan sumber makanan tambahan dari bioflok yang terbentuk. Bioflok tersusun dari bakteri, mikroalga (fitoplankton), zooplankton, protozoa, jamur dan lainya (Avnimelech 2007). Sumber pakan dari bioflok tersebut menyebabkan pertumbuhan ikan pada perlakuan dengan bioflok menghasilkan pertumbuhan yang lebih tinggi dibandingkan dibandingkan dengan yang tidak menggunakan bioflok

\section{Kelangsungan Hidup}

Hasil penelitian menunjukkan bahwa penggunaan bioflok dan tanpa bioflok berbeda berpengaruh nyata $(\mathrm{P}<0.5)$ terhadap kelangsungan hidup pada ikan hias Platydoras. Berdasarkan tingkat 
kelangsungan hidup selama penelitian pada Tabel 3 menunjukkan bahwa nilai rata-rata SR (kelangsungan hidup) pada perlakuan tanpa bioflok sebesar $86.08 \pm 2.60 \%$ dan pada perlakuan bioflok sebesar $75.67 \pm 3.90 \%$. Salah satu dampak dari penggunaan teknologi bioflok adalah meningkatnya kekeruhan akibat kepadatan tersuspensii (Ekasari 2008). Nilai kekeruhan pada perlakuan bioflok relatif tinggi yaitu mencapai 86 NTU, nilai kekeruhan diatas 80 NTU menyebabkan ikan stress (Bhatnagar dan Devi 2013). Stress yang berkepanjangan akan menyebabkan kematian pada ikan (Wedemeyer 1996), hal inilah yang menyebabkan kelangsungan hidup ikan pada teknologi bioflok lebih rendah dari pada perlakuan tanpa bioflok. Kekeruhan yang tinggi menyebabkan ikan sulit bernafas, sehingga ikan menjadi mati. Kekeruhan diakibatkan adanya kepadatan flok dan bakteri pada media percobaan, sisa pakan, feses dan urin dari ikan.

\section{Kepadatan Bakteri}

Pemanfaatan bioflok sebagai sumber pakan bergantung pada spesies dan kebiasaan makannya, ukuran ikan, kepadatan flok dan ukuran flok. Struktur flok dipengaruhi kandungan oksigen terlarut, kecenderungan flok yang lebih besar dan kompak terjadi pada kandungan oksigen yang tinggi., sedangkan kandungan oksigen terlalu rendah menyebabkan dominasi bakteri filamen pada bioflok yang akan menyebabkan bioflok cenderung terapung, karena bakteri filament cenderung membentuk ikatan flok (De Schryver et al. 2008).

Kepadatan bakteri di awal penelitian (9.6x104 $\mathrm{CFU} / \mathrm{ml})$, pada akhir penelitian memiliki nilai rata-rata pada perlakuan tanpa bioflok sebesar $7.84 \times 10^{5} \mathrm{CFU} / \mathrm{ml}$ sedangkan nilai rata-rata pada perlakuan bioflok sebesar $4,30 \times 10^{6} \mathrm{CFU} / \mathrm{ml}$. Hasil ini menunjukkan bahwa kelimpahan bakteri meningkat dikarenakan adanya pemanfaatan $\mathrm{N}$ di media pemeliharaan dan karbon (molase) yang ditambahkan sebagai sumber nutrien bakteri. Ikan yang dipelihara dapat memanfaatkan bakteri dalam jumlah yang lebih banyak dan pemanfaatan bioflok sebagai sumber pakan untuk mendukung pertumbuhan ikan.
Hasil identifikasi pada awal penelitian terdapat 5 jenis bakteri yaitu Streptobacillus sp, Bacillus sp, Enterobacter sp, Kurthia sp, Aeromonas sp. sedangkan pada akhir penelitian terdapat 2 jenis bakteri pada perlakuan tanpa bioflok dan 2 jenis bakteri pada perlakuan bioflok. Pada perlakuan tanpa bioflok ditemukan 2 jenis bakteri dominan yaitu Entrobacter sp dan Bacillus sp. dan pada perlakuan bioflok ditemukan 2 jenis bakteri dominan yaitu Aeromonas sp dan Kurthia sp. Pada penelitian ini hasilnya berbeda dengan yang diperoleh (Widanarni et al. 2013) pada budidaya ikan nila merah dengan teknologi bioflok yang mendapatkan 6 jenis bakteri dominan yaitu Bacillus, Kurthia, Listeria, Alcaligenes, Entrobacteria dan acinetobacter. Bakteri yang tumbuh dominan bakteri heterotroph dapat menjadi sumber pakan untuk pertumbuhan ikan, bakteri-bakteri yang terdapat pada penelitian ini bersifat baik (Widanarni et al. 2013).

\section{Kualitas Air}

Kualitas air sangat berperan penting dalam menunjang laju pertumbuhan dan kelangsungan hidup ikan hias Platydoras. Kualitas air pada media pemeliharaan bioflok dimana tanpa ada pergantian air mendukung pertumbuhan yang sama dengan media pemiliharaan tanpa bioflok yang setiap hari dilakukan pergantian air sebanyak 30\%. Hasil pengukuran kualitas air pemeliharaan dengan teknologi bioflok dan bioflok (Tabel 5) memberikan hasil yang sama kecuali kekeruhan, dimana yang bioflok lebih tinggi hasilnya dibandingkan dengan yang tanpa bioflok. Menunjukkan bahwa nilai suhu berkisar $26.9-27.9^{\circ} \mathrm{C}$ pada perlakuan tanpa bioflok dan pada perlakuan bioflok berkisar 26.9-27.8 ${ }^{\circ} \mathrm{C}$. Sedangkan suhu dalam pemeliharaan ikan hias Platydoras berkisar 24-30 ${ }^{\circ} \mathrm{C}$ menurut (Axelrod et al. 1988; Satyani 2005). Dengan demikian suhu yang diperoleh selama penelitian mendukung untung pertumbuhan ikan hias Platydoras.

Hasil pengukuran $\mathrm{pH}$ selama penelitian pada perlakuan tanpa bioflok berkisar antara 6,1-6.5 pada perlakuan dengan menggunakan bioflok berkisar 6.1-6.6. sedangkan $\mathrm{pH}$ dalam pemeliharaan ikan hias Platydoras berkisar 6- 
8 menurut (Axelrod et al. 1988; Satyani 2005), dengan demikian $\mathrm{pH}$ yang diperoleh selama penelitian mendukung untung pertumbuhan ikan hias Platydoras.

Hasil pengukuran oksigen terlarut dalam air selama penelitian pada perlakuan tanpa bioflok berkisar antara 5.9-7.7 ppm pada perlakuan dengan menggunakan bioflok berkisar 5.5-7.2 ppm. sedangkan oksigen terlarut dalam pemeliharaan ikan hias Platydoras berkisar minimal 3 ppm (Axelrod et al. 1988; Satyani 2005). Dengan demikian oksigen terlarut dalam air yang diperoleh selama penelitian mendukung untung pertumbuhan ikan hias Platydoras. .

Hasil pengukuran TAN selama penelitian pada perlakuan tanpa bioflok berkisar 0.0030.843 pada perlakuan dengan menggunakan bioflok berkisar 0.003-1.092 $\mathrm{mg} / \mathrm{l}$, namun nilai ini masih dalam ambang batas budidaya ikan Platydoras yakni $2 \mathrm{mg} / \mathrm{l}$, menurut (Boyd 2008) konsentrasi TAN di atas $2 \mathrm{mg} / \mathrm{l}$ menyebabkan tingkat ammonia dapat mempengaruhi fisiologi dan pertumbuhan ikan, semakin tinggi ammonia menyebabkan semakin tinggi konsentrasi plasma kortisol dan glukosa, yang mengindikasikan kondisi stres. Akibat selanjutnya tingginya ammonia memiliki resiko mengurangi asupan pakan 10\% (Schram et al. 2010).

\section{KESIMPULAN DAN IMPLIKASI}

Ikan Platydoras yang dipelihara dengan teknologi bioflok menghasilkan nilai pertumbuhan yang lebih baik dibandingkan tanpa bioflok, namun nilai kelangsungan hidupnya lebih rendah. Melakukan penelitian lanjutan dengan kepadatan ikan Platydoras yang berbeda, melakukan penelitian teknologi bioflok pada jenis ikan hias berbeda dan melakukan penelitian teknologi bioflok dengan $\mathrm{C} / \mathrm{N}$ ratio yang berbeda.

\section{DAFTAR PUSTAKA}

Avnimelech Y. 2007. Feeding With Microbial Flocs by Tilapia in Minimum Discharge Bio-flocs Technology Ponds. Aquaculture $264: 140-147$
Avnimelech Y. 2012. Biofloc Technology. A Practical Guide Book. Second Edition. Louisiana (US). World Aquaculture Society.

Axelrod HR, Emmens CW, Sculthorpe D, Vorderwinkler W, Pronek N, Burgess WE, 1988. Exotic Tropical Fishes. Edisi 29. US. T,F.H, Publications Inc. 608 p.

Browdy CL, Ray AJ, Leffler JW, Avnimelech Y. 2012. Biofloc-based Aquaculture Systems. in : Tidwell JH, editor. Aquaculture Production Systems. US. Willey Blackwell

Bhatnagar A, Devi P. 2013. Water Quality Guidelines for the Management of Pond Fish Culture. International Journal of Environment Sciensces 3 (6) ; 1980-2009

Diatin I dan E Harris. 2014. Inovasi Teknologi Bioflok pada Ikan Hias Ekspor Corydoras $s p$ di dalam Budidaya Intensif Ramah Lingkungan. LPPM. IPB

De Souza DM, Suita SM, Romano LA, Wasielesky WJr, Ballester ELC. 2012. Use of Molasses as a Carbon During the Nursery Rearing Farfantepenaeus brasilliensis (Latreille, 1817) in A Biofloc Technology System. Aquaculture Research 1-8

De Schryver P, Crab R, Defoirdt T, Boon N, Verstraete W. 2008. The Basics of Bio-flocs Technology : The Added Value for Aquaculture. Aquaculture 277: 125-137.

De Schryver P, Verstraete W. 2009. Nitrogen Removal From Aquaculture Pond Water by Heterotrophic Nitrogen Assimilation in Lab-scale Sequencing Batchreactors. Bioresource Technology 100 : 1162-1167

Ekasari J. 2008. Bio-flocs technology : The Effect of Different Carbon Source, Salinity and the Addition of Probiotics on the Primary Nutritional Value of the Bio-flocs [Tesis]. Gent (BE). Universiteit Ghent.

Goddard S. 1996. Feed Management in Intensive Aquaculture. Chapman \& Hall. USA.194 p.

Satyani D. 2005. Catfish Kecil Unik, Corydoras sp. untuk Akuarium, Tingkah Laku Biologi dan Reproduksinya. Jurnal iktiologi Indonesia vol 3 no 1 : 15-18

Schram E, Roques JAC, Abbink W, Spanings T, de Vries P, Bierman S, de Vis H, Flik G. 2010. The Impact of Elevated Water Ammonia Concentration on Physiology, 
Growth and Feed Intake of African Catfish (Clarias gariepinus). Aquaculture 306 : 108- 115.

Wang G, Yu E, Xie J, Luo W, Qiu L, Zheng Z. 2015. Effect of C/N Ratio on Water Quality in Zero-water Exchange Tanks and the Biofloc Supplementation in Feed on the Growth Performance of Crucian Carp
Carrasius auratus. Aquaculture 443 : 98104

Widanarni, Yuniasari D, Sukenda, Ekasari J. 2013. Nursery Culture Performance of Litopenaeus Vannamei with Probiotics Addition ang Different C/N Ratio Under Laboratory Condition. Hayati Journal of biosciences 17 (3) : 115-119. DOI: 10.4308/hhjb. 17.3.115. 